\title{
Editorial
}

\section{International Sports Law Journal (2014) 14:3-4}

\author{
Jack Anderson
}

Published online: 9 September 2014

(C) T.M.C. Asser Instituut 2014

If there is a downside to the continued development of sports law, it is trying to keep up to date with the burgeoning jurisprudence and related commentary. Websites and social media platforms dedicated to sports law have emerged and are most useful for the student, scholar, practitioner and policy maker. Of course academic periodicals are also effective in the slightly more reflective manner in which they consider sports law matters. This edition of ISLJ, it is hoped, will assist you in this regard and again the topics contained in this issue reflect the growing breadth and depth of sports law and sports law scholarship.

One of the subjects to catch this editor's eye recently is the impact on sport of EU "state aid" law and on which Dr Richard Craven of Northumbria Law School is the leading scholar.

The objective of state aid control as established by the treaty on the Functioning of the European Union (TFEU) is to ensure that government interventions do not distort competition and intra-EU trade. Article 107 TFEU contains a general prohibition on all state aid measures, subject to the possibility for the EU Commission to authorise aid measures in line with a series of defined objectives. According to Article 108(3) TFEU, aid measures can only be put into effect once the Commission has approved them.

In the context of sports law, these provisions of the TFEU have been discussed mainly in light of policies, which purport to grant economic advantage to professional football clubs and notably in Spain where investigations are ongoing by the EU Commission into certain advantages relating to tax rates, property deals and even bank loan

J. Anderson ( $\square)$

Belfast, BT, UK

e-mail: jack.anderson@qub.ac.uk guarantees to the benefit of leading clubs such as Real Madrid and Barcelona.

The above investigation, which thus far has been characterised only by its tardiness, is taking place in the context of the EU Commission's wholly positive view of UEFA's Financial Fair Play Regulations (FFP) and in particular FFP's principal objective of introducing more discipline and rationality in football club finances. Indeed, in a joint statement in March 2012 with UEFA President Michel Platini, the Vice-President and Competition Commission of the EU, Joaquin Almunia, agreed that the principles underlying FFP "could serve with adaptations, as an effective model for other sports facing similar financial challenges".

Whether FFP can be exported elsewhere remains to be seen but what is of interest is that the prohibition in Article 107 TFEU is not by any means a blanket ban and state aid assisting the development of certain economic activities, with a sporting impact, is permissible. An interesting sports-related application in this regard occurred in April of this year when the EU Commission concluded that plans in Northern Ireland to grant $€ 130$ million for the reconstruction of three sports stadiums in Belfast was consistent with EU State aid rules. The Commission found that the proposed funding would contribute to urban regeneration and social cohesion, in line with EU objectives, without unduly distorting competition in the single market.

The aid, granted through the regional budget of the Northern Ireland Assembly is being shared between three beneficiaries and translating EU-speak ("social cohesion") into Northern Ireland-speak ("a peace dividend"); this means that, by and large, the money is being divided among sports that appeal to the two main communities in Northern Ireland (unionist and nationalist) i.e., the Irish Football Association for Windsor Park Stadium (€37 
million), the Gaelic Athletic Association for Casement Park Stadium (€75.4 million) and the Ulster Branch of the Irish Rugby Football Union for Ravenhill Stadium (€20 million).

In 2013, when the UK authorities notified the EU Commission of its plans to rebuild the three old sports stadiums in Belfast, they also made a number of other points supporting an exemption for the normal prohibitory remit of Article 107 TFEU, which the Commission subsequently accepted. Many of the points made by the UK authorities are also in line with the EU's current Erasmus+ programme (developing the European dimension to sport) and the EU work plan for sport (2014-2017), which in turn have developed under the competence assigned to the EU by Article 6 and Article 165 TFEU, according to which sport is an area where action at EU level should support, coordinate and supplement the actions of Member States for inter alia promoting voluntary activities, social inclusion, and equal opportunities in sport; raising awareness of the health benefits of physical activity; and increasing participation in sports.

In this, the UK authorities stressed that any surplus money in the stadia projects in Belfast would be invested in grassroots and community projects by the aid beneficiaries and that the project intended to raise participation levels in sport and physical recreation generally in Northern Ireland. The UK authorities also highlighted that the investment would aim to improve the health of the population and to increase Northern Ireland's sporting profile through better playing and training facilities and addresses a specific problem of under-investment in local sports infrastructure. Accordingly, it was unsurprising that the Commission found that reconstruction of all three venues met public interest policy objectives. Equally, it was also unsurprising that the Commission concluded that the professional activities planned for the sports venues in Belfast would likely be of a local character and the aid therefore would not affect trade in the single market to an extent contrary to the common interest of the EU.

In sum, the above snapshot into state aid amply demonstrates the growing linkages between sports policy and the law and that the competency granted to the EU in sport pursuant to Article 165 TFEU is, at last, coming alive.

Finally and as ever, I look forward to any thoughts you might have on the future direction of the International Sports Law Journal. The editorial team at ISLJ is particularly interested in ideas for special editions of the ISLJ on current topics of interest and on an individual basis we also especially welcome contributions from outside the EU/US sphere of influence. Sport's reach is now global and the ISLJ seeks to reflect that. In all of the above, please do not hesitate to contact me if you wish to discuss further. For now, I hope that you enjoy the current issue.

Jack Anderson

Editor-in-Chief

International Sports Law Journal 